\title{
DIREITO CIVIL À LUZ DA CONSTITUIÇÃO: ASPECTOS PRÁTICOS DA USUCAPIÃO ESPECIAL URBANA POR ABANDONO DO LAR
}

\section{CIVIL RIGHTS UNDER THE CONSTITUTION: PRACTICAL ASPECTS OF ADVERSE POSSESSION SPECIAL URBAN BY ABANDONMENT THE HOME}

\section{Resumo}

O presente trabalho versa sobre os efeitos práticos da usucapião especial urbana por abandono do lar, um novo modo de aquisição da propriedade imobiliária inserido no Código Civil brasileiro em meados de 2011. Dessa forma, serão analisados todos os requisitos estabelecidos pelo aludido diploma legal para a sua caracterização, de modo a construir não apenas conclusões, mas, também, propostas para uma aplicação adequada do instituto na ordem jurídica nacional. Tudo isso à luz do conjunto de regras, princípios e valores constitucionais que delineiam tanto o Direito de Família quanto o Direito de Propriedade, a partir da compreensão do atual cenário do Direito Civil, marcado pela releitura de seus institutos à luz da Constituição da República, e do sentido da entidade familiar contemporânea, ambiente sobre o qual incidirão os efeitos práticos dessa forma de aquisição prescritiva.

Palavras-chave: Usucapião familiar. Aplicação. Efeitos práticos.

\begin{abstract}
The paper aims to study the practical effects of adverse possession by home abandonment, a new form of acquisition of real property recently introduced in Brazilian Civil Code. Thus, all the requirements established by law for its characterization will be analyzed, building not only conclusions but also proposals to a proper application of this institute in Brazilian law. All this based on a set of rules, principles and constitutional values that delineate both the Family Law and the Rights of Property, starting from an understanding of the current scenario of the Civil Law, characterized by the reinterpretation of its institutes based in the Constitution, and the meaning of contemporary family, an environment where the practical effects of this form of adverse possession will focus.
\end{abstract}


Keywords: Familiar adverse possession. Application. Practical Effects.

\section{INTRODUÇÃO}

A família consiste em uma realidade sociológica que integra a base do Estado, sendo o núcleo fundamental em que repousa toda organização social. Em quaisquer de suas vertentes, ela se apresenta como uma instituição necessária e sagrada, que merece a mais extensa proteção estatal (FARIAS; ROSENVALD, 2012a, p. 38).

$\mathrm{Na}$ sociedade contemporânea, a natureza do agrupamento familiar adquire traços instrumentais, que o caracterizam como um núcleo para a promoção da pessoa humana e não da finalidade desejada (FARIAS; ROSENVALD, 2012a, p. 42). Como consequência, a entidade familiar atual deve ser compreendida como um instrumento de realização da personalidade e da dignidade de seus membros (LIMA, 2009, p. 02).

Influenciado por esse contexto de especial proteção estatal e de instrumentalização da família para o desenvolvimento de seus integrantes, desde junho de 2011 está em vigor, no Brasil, um novo modo de aquisição da propriedade imobiliária, a usucapião especial urbana por abandono do lar ${ }^{1}$.

Inserida no Código Civil, por intermédio do artigo 1.240-A, acrescentado pela Lei $\mathrm{n}^{\circ}$ 12.424 de 16 de junho de 2011, que estabelece disposições acerca do programa habitacional "Minha Casa Minha Vida" do governo federal, a referida usucapião vem desafiando os juristas e estudiosos do Direito, principalmente quanto aos seus efeitos no ordenamento jurídico nacional.

As primeiras impressões apontam para a conclusão de que, transcorrido determinado lapso temporal, o cônjuge ou companheiro que abandona o lar pode ter a sua meação referente ao imóvel usucapida pelo outro que permanecer exercendo a sua posse, desde que estejam caracterizadas as demais exigências estabelecidas na lei.

A partir da leitura do artigo 1.240-A, é possível elencar como requisitos cumulativos e necessários para a ocorrência da usucapião: (i) posse, (ii) prazo de dois anos ininterruptos, (iii) imóvel urbano comum do casal, (iv) abandono do lar e (v) a destinação desse imóvel para moradia da pessoa desamparada ou de sua família.

\footnotetext{
${ }^{1}$ Vale destacar que o nomen iuris do instituto não está pacificado na doutrina, sendo por vezes denominado de usucapião pro-família, usucapião familiar, usucapião especial por abandono do lar ou usucapião conjugal. Todas essas terminologias se referem à usucapião tratada no presente estudo.
} 
Sendo assim, por intermédio da aplicação da tipologia jurídico-prospectiva, vez que o trabalho se orienta pela proposta de identificação das tendências futuras na aplicação do recente instituto, cumpre analisar, a partir da pesquisa de ensinamentos doutrinários acerca da família e da propriedade, cada um desses requisitos, com o intuito de se estabelecer o atual retrato da usucapião especial urbana por abandono do lar no sistema normativo brasileiro.

\section{O CENÁRIO DA APLICAÇÃO DA USUCAPIÃO ESPECIAL URBANA POR ABANDONO DO LAR: CONSTITUCIONALIZAÇÃO DO DIREITO CIVIL}

No atual cenário do Direito Civil, qualquer de seus elementos só se mostra legítimo caso encontre fundamento na Constituição da República, diploma unificador de todo o sistema, o qual estabelece a tábua axiológica a ser respeitada e seguida em todas as relações sociais. Vale ressaltar que essa é uma constatação que também circunscreve a usucapião especial urbana por abandono do lar, cuja existência encontra relação direta com a doutrina civil-constitucional.

É importante frisar: a aplicação dessa nova forma de aquisição prescritiva só se mostra possível caso tenha como base o Direito Civil à luz da Lex Fundamentalis, em outras palavras, o Direito Civil fundado em paradigmas pós-modernos, de valorização da pessoa e de sua dignidade em detrimento de seu patrimônio.

Sendo assim, é preciso desenvolver um breve estudo acerca do fenômeno da constitucionalização do Direito Civil, tendo em vista tratar-se de um movimento que desempenha a função de alicerce e de pressuposto para a interpretação e a compreensão adequada dos efeitos práticos da usucapião abordada.

Nessa linha de raciocínio, não há efeito prático legítimo da aludida forma de aquisição prescritiva que não encontre sustentação no texto constitucional, de modo que estudar a influência desse diploma normativo no Direito Civil significa projetar as maneiras adequadas de se aplicar a usucapião por abandono do lar.

De início, é cediça a constatação de que a unidade do Direito Civil não tem mais como fundamento os códigos civis, mas o conjunto de princípios e regras estabelecidos pela Constituição e os tratados internacionais, em torno dos quais perpassam os microssistemas jurídicos que se referem a matérias a ele vinculadas (LÔBO, 2005, p. 01).

O crescimento da legislação esparsa sob a forma dos estatutos especializados traduz a incoerência em se afirmar a centralidade do Código em face desse verdadeiro polissistema, o 
qual passa a encontrar, agora, sua unidade sistemática e axiológica na Constituição (MORAES, 2006, p. 234-235).

No entanto, durante toda a sua história no mundo romano-germânico, em especial no período posterior às grandes codificações, o Direito Civil sempre foi identificado como um âmbito normativo privilegiado do indivíduo, nessa qualidade. Assim, "nenhum ramo do direito era mais distante do direito constitucional do que ele" (LÔBO, 2005, p. 01).

Ao longo de sua lenta elaboração - que vem perpassando a história do direito romanogermânico há mais de dois mil anos - o Direito Civil parecia adverso às mutações sociais, políticas e econômicas, de maneira a aparentar que as relações jurídicas interpessoais não seriam afetadas pelos acontecimentos históricos, pouco importando que tipo de constituição política fosse adotado (LÔBO, 2005, p. 02).

Contudo, os estudos mais recentes relativos à seara civilista têm demonstrado o engano dessa visão estática, atemporal e desideologizada do Direito Civil. Além disso, na atualidade, não se busca mais realizar a separação dos seus espaços distintos e até contrapostos. Enquanto que antes havia a disjunção, hoje a unidade hermenêutica se mostra presente, sendo a Constituição o elemento conformador da elaboração e aplicação da legislação civil (LÔBO, 2005, p. 02).

Vão desaparecendo lentamente as influências do contexto histórico burguês e liberal em que o Direito Civil se originou, voltado exclusivamente para a proteção do patrimônio e para a tutela da propriedade e da autonomia privada de cunho econômico, elevando o Código Civil à qualidade de núcleo do sistema (MORAES, 2006, p. 234).

Vale ressaltar que a inadequação do aludido Código para os desafios da sociedade pósindustrial constitui um dos sintomas da crise que atingiu o direito na segunda metade do século XX, ocasionando o surgimento de críticas acerca da codificação e o desenvolvimento de um processo de inter-relacionamento do Direito Civil com o Direito Constitucional, dando origem à constitucionalização do Direito Civil (AMARAL, 2008, p. 191).

Ademais, é bem verdade que esse Direito, tendo em vista sua mais antiga evolução, sempre ofereceu categorias, conceitos e classificações que fundamentaram a consolidação de diversos ramos do Direito Público, inclusive o Constitucional. Porém, o Direito Civil encaminha-se, agora, para a mesma sujeição aos valores, princípios e regras consagrados na Constituição $^{2}$ (LÔBO, 2005, p. 02).

\footnotetext{
${ }^{2}$ Paulo Lôbo (2005, p. 02, grifo nosso) ressalta, inclusive, ser essa a origem da "necessidade que sentem os civilistas do manejo das categorias fundamentais da Constituição. Sem elas, a interpretação do Código e das leis civis desvia-se de seu correto significado".
} 
Consequentemente, em virtude de tutelar institutos de origem civilista, como a família e a propriedade, o legislador constituinte alterou o enfoque da norma privada, por intermédio da fixação de parâmetros fundamentais interpretativos (GONÇALVES, 2011, p. 44) que devem influenciar a sua utilização no caso concreto.

A fundamentação constitucional do Direito Privado não representa mera exceção circunstancial, mas imposição permanente em sua aplicação, com o intuito de se combater a aparente auto-suficiência da legislação civil, em especial com o advento de um novo Código Civil, tradicionalmente mais estável que a Constituição, sob o risco de seu envelhecimento $\operatorname{precoce}^{3}$ (LÔBO, 2005, p. 02-03).

Atualmente, os princípios mais relevantes e as disposições fundamentais acerca da matéria tratada no presente trabalho são objetos da Constituição da República de 1988. Seja no que diz respeito à função social da propriedade, à dignidade da pessoa humana ou à estrutura da própria família, o texto constitucional sempre deve prevalecer, bem como devem ser de acordo com ele as interpretações procedentes das normas de Direito Privado (WALD, 2011, p. 37-38).

A partir dessa perspectiva, tem-se constatado o nascimento de uma nova disciplina ou ramo metodológico denominado Direito Civil-Constitucional, que tem como objeto o estudo do Direito Privado à luz das regras constitucionais. Dessa forma, Carlos Roberto Gonçalves confere destaque ao:

[...] fenômeno que vem se desenvolvendo atualmente da acentuada interferência do direito público em relações jurídicas até agora disciplinadas no Código Civil, como [...] as concernentes ao direito de família e ao direito de propriedade, reguladas na Constituição Federal de 1988, a ponto de se afirmar hoje que a unidade do sistema deve ser buscada, deslocando para a tábua axiológica da Carta da república o ponto de referência antes localizado no Código Civil (GONÇALVES, 2011, p. 45 , grifo nosso)

Nesse sentido, pode-se afirmar que o Direito Civil-Constitucional tem como fundamento uma visão unitária do sistema. Não há que se falar em interpretação isolada do Direito Público ou do Direito Privado, mas, sim, em uma interpretação sistemática, levando em consideração toda a ordem jurídica, por intermédio de uma verdadeira interação simbiótica entre ambos os Direitos (GONÇALVES, 2011, p. 45).

\footnotetext{
${ }^{3}$ Em relação a essa maior estabilidade aparente do Direito Civil, em virtude de sua evolução ao longo da história, Maria Celina Bodin de Moraes (2006, p. 235) assevera que: "A suposta segurança oferecida pela estrutura milenar do direito civil clássico, que justificaria seu predomínio sobre a instável normativa constitucional, revela-se como apenas mais um mito elaborado para a manutenção do status quo individualista e patrimonialista".
} 
A interpretação do Código Civil deve ser realizada segundo a Constituição, e não o contrário, uma vez que a fonte primária do Direito Civil é a própria Lei Maior, a qual, com seus princípios e regras, estabelece uma nova perspectiva à ciência civilista (GONÇALVES, 2011, p. 45). Nesse sentido, mencione-se que sua constitucionalização é o processo de elevação ao plano constitucional dos princípios fundamentais do Direito Civil (LÔBO, 2005, p. 03).

A expressão "Direito Civil-Constitucional" tão somente ratifica a necessária releitura do Código Civil e das demais leis especiais à luz da Constituição, redimensionando as categorias jurídicas civilistas a partir dos fundamentos principiológicos constitucionais, incluindo-se, especialmente, a dignidade da pessoa humana, a solidariedade social e a igualdade substancial (GONÇALVES, 2011, p. 45).

Não é possível relegar a norma constitucional, situada no topo do sistema hierárquico das regras, a instrumento de integração subsidiário, aplicável somente quando da ausência de norma ordinária específica e após terem sido frustradas as tentativas de se fazer o uso de analogia e de regra consuetudinária (TEPEDINO, 2001, p. 03).

Desse modo, a funcionalização dos institutos clássicos do Direito Civil às finalidades e valores superiores estatuídos pela Constituição tornou-se um reflexo necessário do respeito obrigatório ao sistema hierárquico das fontes (MORAES, 2006, p. 235) normativas do ordenamento jurídico brasileiro.

\section{O AMBIENTE SOBRE O QUAL INCIDIRÃO OS EFEITOS PRÁTICOS DA USUCAPIÃO ESPECIAL URBANA POR ABANDONO DO LAR: ENTIDADE FAMILIAR CONTEMPORÂNEA}

Além da constitucionalização do Direito Civil, a aplicação da usucapião especial urbana por abandono do lar também depende diretamente de uma mudança de compreensão acerca da própria organização familiar, dissociando-a de valores eminentemente patrimoniais para atribuir-lhe feição humanista, multifacetada, plural e instrumental.

O entendimento do conteúdo da entidade familiar contemporânea não só viabiliza a aplicabilidade da aludida forma de aquisição prescritiva como também a justifica, delimitando os contornos dentro dos quais o jurista deve interpretar o instituto. Assim, compreender a família contemporânea representa entender o porquê da instituição da usucapião, a forma e os limites de sua aplicação prática. 
Em cada sociedade e a partir dos mais diversos valores, são conferidas concepções diferentes ao agrupamento familiar, tendo em vista a influência das circunstâncias de tempo e lugar. Isso significa dizer que o fenômeno familiar é objeto de um permanente processo evolutivo (FARIAS; ROSENVALD, 2012a, p. 46), sendo um instituto social que sofre transformações diárias.

Como consequência do avanço cultural, tecnológico e científico da sociedade atual, pode-se identificar a abolição dos preceitos consolidados no sistema jurídico clássico, os quais se quedam diante de uma família contemporânea, plural, aberta e multifacetada, que encontra sintonia com os aspectos da nova sociedade (FARIAS; ROSENVALD, 2012a, p. 42).

A modificação da família como núcleo econômico para uma acepção igualitária, instrumentalizada para o desenvolvimento da personalidade de seus integrantes, confirma uma nova perspectiva, que encontra sustentação no afeto. Com isso, a entidade familiar se traduz em um espaço no qual os seres humanos se complementam e se completam (FARIAS; ROSENVALD, 2012a, p. 42).

Nos dizeres precisos de Cristiano Chaves de Farias e Nelson Rosenvald (2012a, p. 42, grifo nosso): “ [...] abandona-se, assim, uma visão institucionalizada, pela qual a família era, apenas, uma célula social fundamental para que seja compreendida como núcleo privilegiado para o desenvolvimento da personalidade humana".

As diversas modificações havidas nas estruturas políticas, econômicas e sociais projetaram efeitos nas relações familiares, de modo que os valores do pluralismo, solidarismo, democracia, igualdade, liberdade e humanismo fizeram com que a entidade familiar se voltasse à tutela da pessoa humana (DIAS, 2010, p. 40).

Atento ao fato de que a família não mais representa um centro econômico e reprodutivo, o legislador infraconstitucional, privilegiando o caráter sócio-afetivo das relações familiares, instituiu a usucapião especial urbana por abandono do lar, de modo a impedir que um dos cônjuges utilize a família como instrumento para a manutenção de direitos sobre determinado bem de raiz.

Ademais, quando da análise específica dos requisitos para a caracterização dessa forma de aquisição prescritiva, perceber-se-á a grande influência dos valores da família contemporânea, orientados para a tutela de seus componentes e para a promoção de preceitos constitucionais.

\section{POSSE}


A usucapião, de forma geral, pode ser conceituada como um modo originário de aquisição da propriedade e de outros direitos reais, em virtude da posse prolongada da coisa, desde que cumpridos os demais requisitos legais (FARIAS; ROSENVALD, 2012b, p. 396). Sendo assim, pode-se perceber que, independentemente da modalidade de usucapião, é imprescindível a existência da posse para a sua configuração.

À margem de toda a discussão relativa às teorias da posse, sabe-se que pela letra do Código Civil, que se filiou à teoria objetiva de Ihering ${ }^{4}$, o possuidor é aquele que, em seu próprio nome, exterioriza certas faculdades da propriedade, seja ele proprietário ou não. O conceito de posse, porém, que melhor se adéqua à usucapião especial urbana por abandono do lar engloba os elementos permanência, habitação e produção econômica sustentável, ou seja, é orientado pela visão da posse em sintonia com seus fins sociais (FARIAS; ROSENVALD, 2012b, p. 67).

Segundo as teorias sociológicas da posse ela não é tão-somente um apêndice da propriedade ou sua mera aparência. Pelo contrário, deve ser reinterpretada de acordo com os valores sociais nela impregnados, como um verdadeiro poder fático de ingerência socioeconômica sobre determinado bem da vida (FARIAS; ROSENVALD, 2012b, p. 74).

E quais seriam os valores sociais impregnados na posse capazes de justificar a configuração da usucapião especial urbana por abandono do lar? Ora, todos aqueles que se referem à tutela constitucional do núcleo familiar, quais sejam: (i) dignidade da pessoa humana; (ii) solidariedade social e familiar; (iii) boa-fé objetiva; (iv) especial proteção à família; (v) função social da propriedade; (vi) direito ao mínimo existencial; (vii) direito à moradia, entre outros.

A própria usucapião, vale frisar, aquisição da propriedade por intermédio da posse prolongada no tempo, relaciona-se diretamente com a concretização de diversos valores sociais, porquanto se ampara na pacificação da sociedade - vez que evita disputas futuras que envolvam o bem de raiz - e na efetivação do interesse social.

Nesse contexto, tal instituto tem como fundamentos o princípio da utilidade social e a convivência de se dar segurança e estabilidade à propriedade. Ademais, “[...] repousa na paz social e estabelece a firmeza da propriedade, libertando-a de reivindicações inesperadas, corta

\footnotetext{
${ }^{4}$ Pelo fato de o trabalho mencionar aspectos contemporâneos do direito civil, cumpre destacar os ensinamentos de Cristiano Chaves de Farias e Nelson Rosenvald (2012b, p. 66) referentes às teorias clássicas da posse, no sentido de que: "[...] nos dias atuais, no âmbito de uma sociedade plural, as teorias de Savigny e Ihering não são mais capazes de explicar o fenômeno possessório à luz de uma teoria material dos direitos fundamentais. Mostram-se envelhecidas e dissonantes da realidade social presente. Surgiram ambas em momento histórico no qual o fundamental era a apropriação de bens sob a lógica do ter em detrimento do ser [...].”.
} 
pela raiz um grande número de pleitos, planta a paz e a tranqüilidade na vida social [...]" (GONÇALVES, 2010, p. 258).

Por sua vez, a primeira consideração pertinente à análise do requisito posse perpassa pelo seu entendimento como fenômeno de relevante influência social, modulado, sobretudo, por princípios, regras e valores constitucionais que fundamentam a harmonia da mencionada usucapião com o ordenamento jurídico brasileiro.

De acordo com Ana Rita Vieira de Albuquerque, citada por Cristiano Chaves de Farias e Nelson Rosenvald, o instituto da posse:

[...] não pode deixar de receber esse influxo constitucional, adequando as suas regras à ordem constitucional vigente como forma de cumprir a sua função de instituto jurídico, fruto do fato social em si, verdadeira emanação da personalidade humana e que, por isso mesmo, é ainda mais comprometido com os próprios fundamentos e objetivos do Estado Democrático e a efetividade do princípio da dignidade da pessoa humana (FARIAS; ROSENVALD, 2012b, p. 75).

Nesse sentido, é imprescindível que, no contexto da usucapião especial urbana por abandono do lar, seja realizada a tutela da posse como direito especial, tendo em vista a própria relevância do direito de possuir, em sintonia com a previsão constitucional do direito social primário à moradia e o acesso aos bens mínimos capazes de conceder dignidade à pessoa humana (FARIAS; ROSENVALD, 2012b, p. 75) ${ }^{5}$, conferindo-lhe uma existência digna.

O Estado brasileiro, em atenção aos preceitos constitucionais anteriormente mencionados, decidiu tutelar a situação jurídica caracterizada pela posse do indivíduo desamparado no âmbito familiar, estabelecendo requisitos para que do seu exercício decorresse a aquisição da propriedade imóvel destinada à moradia, em virtude, sobretudo, da função social da posse no direito contemporâneo.

A posse analisada insere-se na figura da posse real, vez que é decorrência da titularidade da propriedade imobiliária pertencente ao casal que originara a entidade familiar. Nesse cenário, o indivíduo desamparado a exercerá sobre o imóvel abandonado pelo cônjuge ou companheiro e cuja propriedade seja com ele dividida, demonstrando, assim, a necessidade de a posse derivar de uma situação de titularidade da propriedade imóvel objeto da referida usucapião.

\footnotetext{
${ }^{5}$ Ressalte-se que, em sua fonte original, os ensinamentos não se referem apenas à posse na usucapião especial urbana por abandono do lar, mas à posse como um todo.
} 
Por outro lado, o dispositivo legal não se contenta com a simples posse do indivíduo desamparado. Pelo contrário, exige que ela seja direta e, além disso, exercida com exclusividade.

Quanto ao primeiro elemento, Carlos Roberto Gonçalves (2010, p. 79-80) ressalta que a clássica distinção entre posse direta e indireta nasce da ramificação da posse plena, em uma clara aplicação da teoria objetiva de Ihering. Por isso, é possível a distinção entre a posse direta (ou imediata) e a posse indireta (ou mediata).

O proprietário pode usar e gozar a coisa, direta e pessoalmente, por intermédio do exercício de todos os poderes abrangidos pelo seu direito, nele se confundindo as posses direta e indireta. Por seu turno, é possível, também, que se transfira o direito de usar a coisa para terceiro. Assim, a posse é dissociada, de maneira que o titular do direito real fica com a posse indireta e aquele mantém a posse $\operatorname{direta}^{6}$ (GONÇALVES, 2010, p. 80).

Para que seja possível a ocorrência da usucapião especial urbana por abandono do lar é imprescindível que a posse do indivíduo desamparado seja exercida de maneira direta. Isso significa que os seus desdobramentos não são admitidos, evitando que reste àquele tãosomente a posse indireta.

Em outras palavras, o indivíduo desamparado não pode transferir a outrem, por negócio jurídico ou por qualquer outro meio, o direito de usar a coisa, dando-a em usufruto, em comodato, em penhor, em enfiteuse, o que ratifica a natureza social da referida usucapião, pois confere primazia à dignidade humana da pessoa abandonada em detrimento do caráter patrimonialista existente na tutela dos direitos reais.

Além disso, deve-se combater a constatação de Cristiano Chaves de Farias e Nelson Rosenvald (2012b, p. 466), segundo a qual o legislador, pelo fato de se utilizar da expressão "posse direta" para delinear a situação jurídica do cônjuge que continua no lar comum, não se importou com a boa técnica, em virtude de não existir relação de direito obrigacional ou real entre o casal.

Nesse sentido, Cristiano e Nelson (2012b, p. 466) ressaltam que “[...] o correto é entender que um dos compossuidores se converte em possuidor exclusivo e, posteriormente, no concurso de todos os requisitos legais, único proprietário".

Com a devida vênia, a necessidade de posse direta é extremamente importante para se defender a aplicabilidade do aludido instituto no ordenamento jurídico brasileiro. Ora, um dos preceitos fundamentais capazes de sustentar sua possível aplicação é o direito à moradia.

\footnotetext{
${ }^{6}$ Destaque-se que a divisão da posse em direta e indireta encontra-se muito bem definida no artigo 1197 do Código Civil.
} 
Tanto é assim que o próprio texto legal exige que o bem imóvel objeto da usucapião especial urbana por abandono do lar tenha como destinação a moradia.

Com isso, não se pode defendê-la nas situações em que a posse do indivíduo desamparado se configure de maneira indireta. Isso porque a situação demonstraria, em regra, uma utilização do imóvel com destinação diferente daquela exigida em lei, isto é, desvinculada da moradia. Portanto, não há que se falar em ausência de boa técnica por parte do legislador ordinário.

Por fim, a lei exige que a posse seja personalíssima, o que significa que a sua configuração depende da caracterização do exercício da posse exclusiva sobre o bem imóvel. Mencione-se que a posse é exclusiva nos casos em que só existe um único possuidor. Com isso, uma única pessoa, física ou jurídica, tem, sobre a mesma coisa, posse plena, direta ou indireta (GONÇALVES, 2010, p. 82). No caso da referida usucapião, portanto, é necessária a posse exclusiva direta, por expressa disposição legal.

Nesses termos, caso o abandono se configure, mas o âmbito familiar seja recomposto pela existência de um novo indivíduo, de maneira que a situação demonstre tratar-se de hipótese de composse, em que duas ou mais pessoas exercem, simultaneamente, poderes possessórios sobre a mesma coisa, não há que se falar em usucapião especial urbana por abandono do lar. Por óbvio, tal constatação, diante do caso concreto, pode abrigar importantes exceções.

Essa consequência, aliás, parece estar em sintonia com a natureza do instituto. $\mathrm{Na}$ sociedade contemporânea, o cônjuge ou companheiro - qualquer que seja o seu sexo - antes de abandonar o lar, costuma contribuir com o pagamento das despesas econômicas e com a concretização dos valores familiares positivados na Constituição.

Em certa medida, a usucapião é utilizada como instrumento para se evitar o prejuízo à dignidade humana das pessoas desamparadas, em virtude dessa importância do indivíduo que se ausenta do lar.

Nos casos em que a família passa a ser integrada por um novo membro, capaz de preencher esses anseios, não há mais que se falar em proteção da entidade familiar por intermédio da aquisição da propriedade, pois restaria configurada a perda do objeto da referida usucapião, qual seja, a proteção da família em face dos prejuízos àqueles anseios, oriundos do abandono do lar.

\section{PRAZO DE DOIS ANOS ININTERRUPTOS}


Em relação ao lapso temporal exigido para a aquisição da propriedade por intermédio do instituto, é necessário o transcurso do prazo de dois anos a partir do abandono do lar. Esse é o prazo mais breve de usucapião no direito brasileiro, superando, inclusive, os três anos para a usucapião de bens móveis (FARIAS; ROSENVALD, 2012b, p. 465).

Nesse contexto, a situação mais importante quanto ao prazo para se usucapir perpassa pelo entendimento do marco inicial de sua contagem. A compreensão mais adequada leva à conclusão de que o decurso do tempo apenas começará a fluir quando da vigência da Lei ${ }^{o}$ 12.424/11, isto é, a partir de 16 de junho de 2011 (FARIAS; ROSENVALD, 2012b, p. 466).

Esse é o mesmo raciocínio que preponderou quando da instituição da usucapião urbana pela Constituição da República de 1988 e da usucapião coletiva urbana pela Lei no 10.257/01, prevalecendo, portanto, os princípios da segurança jurídica e da confiança. Nesse sentido, “[...] não pode haver efeito surpresa pelo legislador em face do co-titular do bem com a criação de um novo modelo jurídico, sob pena de confisco e grave lesão ao direito de propriedade" 2011 (FARIAS; ROSENVALD, 2012b, p. 466).

Esse é o posicionamento, inclusive, aprovado na V Jornada de Direito Civil promovida pelo Conselho de Justiça Federal em novembro de 2011, como se pode perceber a partir da leitura de seu Enunciado $n^{\circ} 498$, que estabelece que a fluência do prazo de 2 anos previsto pelo art. 1.240-A para a nova modalidade de usucapião nele contemplada tem início com a entrada em vigor da Lei $n^{\circ} 12.424 / 2011$.

Outrossim, Cristiano Chaves de Farias e Nelson Rosenvald trazem importante afirmação de Adriano Marteleto Godinho, autor da proposta do Enunciado, no sentido de que:

\footnotetext{
Não se pode admitir que os casais que já tiveram os seus laços afetivos extintos antes da edição da Lei n. 12.424/11 venham a invocar de imediato a figura. Assim, somente a partir da entrada em vigor da norma, que ocorreu em 16 de Junho deste ano [2011], será possível iniciar a contagem do lapso temporal exigido pelo legislador, sob pena de se comprometer a segurança jurídica e surpreender o excônjuge ou ex-companheiro a quem se impute o abandono do lar (FARIAS; ROSENVALD, 2012b, p. 467).
}

Por fim, vale destacar a exigência da lei no sentido de que, durante o aludido prazo, o indivíduo desamparado exerça a sua posse sem oposição, o que significa que não há que se falar em usucapião especial urbana por abandono do lar caso haja alguma disputa judicial que envolva a propriedade imobiliária do antigo casal.

Caso o cônjuge ou companheiro abandone o lar e não queira perder o seu direito sobre o bem de raiz, é necessário movimentar a tutela jurisdicional, seja propondo uma ação de 
divórcio ou até mesmo uma ação de separação judicial, demonstrando a sua intenção de resolver a controvérsia instaurada em razão da dissolução da entidade familiar, evitando que o indivíduo ou a família abandonada sofra com essas circunstâncias.

\section{IMÓVEL URBANO COMUM DO CASAL}

Para a ocorrência da usucapião especial urbana por abandono do lar é necessário, também, que os cônjuges ou companheiros sejam comproprietários e compossuidores de um bem imóvel. Além disso, aquele que exercer a pretensão, isto é, o indivíduo desamparado, não pode ostentar a titularidade de qualquer outro bem de raiz em território nacional, sendo desnecessário analisar essa circunstância no patrimônio do ex-convivente (FARIAS; ROSENVALD, 2012b, p. 464).

Por disposição legal, é imprescindível que a propriedade seja dividida por ambos os cônjuges ou companheiros, não sendo possível cogitar a aquisição de imóvel não abarcado pelo regime de bens do casamento ou pelos efeitos da união estável. Por mais que esteja configurado o abandono, não há que se falar em usucapião de propriedade cujo indivíduo desamparado não tenha a titularidade. Isso significa que não se pode admiti-la nas hipóteses de casamento pelo regime da separação absoluta.

Por sua vez, o fracionamento da propriedade pode ser decorrência tanto do matrimônio pela comunhão universal de bens, como pela aquisição onerosa realizada por um dos cônjuges após o casamento pelo regime da comunhão parcial, ou até mesmo por intermédio da demonstração do esforço comum no regime da separação obrigatória. Em relação à união estável, mister se faz a coabitação, a qual pressupõe a convivência exigida em lei para a sua caracterização (FARIAS; ROSENVALD, 2012b, p. 464).

Ademais, a usucapião não é configurada quando a hipótese demonstra se tratar de imóvel de terceiros, isto é, cuja titularidade não seja ostentada por ambos os cônjuges ou companheiros. Ainda que o casal exerça a composse direta, não é possível admitir a usucapião especial urbana por abandono do lar, pois os seus efeitos restringem-se a ambos os cônjuges ou companheiros.

Essa é uma determinação oriunda, sobretudo, da aplicação do princípio da segurança jurídica. Não é possível projetar os efeitos da usucapião a terceiros, tendo em vista a própria finalidade da lei e a constatação de que o prazo da usucapião especial urbana - previsto no artigo 1.240 do Código Civil - a qual pode incidir sobre imóvel de terceiros, é de cinco anos. 
Portanto, admitir a usucapião por abandono do lar incidente sobre imóvel de terceiro significaria um verdadeiro desvio em relação aos princípios e valores familiares que lhe dão fundamento, além de violar frontalmente a segurança jurídica, porquanto, em relação àquele, o prazo definido em lei para se usucapir imóveis urbanos é de cinco anos.

Por fim, essa forma de aquisição prescritiva apenas pode ser concretizada nos casos de imóvel urbano de até duzentos e cinquenta metros quadrados. Essa exigência legal, inclusive, gera muita discussão, tendo em vista as críticas no sentido de que se estaria conferindo privilégios às classes de pessoas mais abastadas.

Contudo, isso não tem o condão de deslegitimá-la como importante instrumento de efetivação de valores constitucionais.

Pouco importando se os destinatários da norma legal são ricos ou pobres, a constatação mais evidente é a de que a lei vem beneficiar, em maioria, as pessoas menos favorecidas. Isso porque quando o indivíduo detém certa capacidade econômica, em ocorrendo a dissolução da entidade familiar, logo há a procura por um advogado, de maneira a solucionar, de plano, a questão patrimonial.

$\mathrm{Na}$ maioria dos casos, a dúvida quanto ao aspecto do patrimônio familiar perdura nas situações de dissolução da família sem condições econômicas, de modo que a utilização da referida forma de aquisição prescritiva tende a se concretizar com maior incidência nessas ocasiões.

\section{ABANDONO DO LAR}

O elemento central da usucapião se assenta na compreensão do abandono do lar. Aliás, talvez seja esse o requisito mais polêmico adotado pelo legislador ordinário, em especial por supostamente retomar a discussão da culpa na dissolução da entidade familiar, elemento que, com base na posição da doutrina majoritária, foi totalmente superada no ordenamento jurídico brasileiro desde a Emenda Constitucional nº 66 de 2010.

Deixando-se de lado as questões polêmicas, vale reconhecer que o abandono do lar é imprescindível para que se conclua pela aplicabilidade do instituto, sobretudo pelo fato de realizar a aproximação entre os princípios e valores pertinentes ao regime jurídico-familiar e a aquisição da propriedade imóvel. 
Sua importância é tão grande que, em questões processuais, por exemplo, a competência para o julgamento da ação de usucapião por abandono do lar pertence à vara de família.

Com isso, cumpre destacar suas principais implicações, objetivando uma melhor definição dos seus efeitos na ordem jurídica brasileira.

\subsection{Da inexistência de discussão a respeito da culpa}

À luz da doutrina majoritária, a Emenda Constitucional no 66 de 2010 se mostraria incompatível com todas as determinações estabelecidas em normas infraconstitucionais referentes à separação e às causas de separação, como, p. ex., o artigo 1.573 do Código Civil, que abarcava, dentre os motivos capazes de configurar a impossibilidade de comunhão de vida, o abandono voluntário do lar conjugal (FARIAS; ROSENVALD, 2012b, p. 465).

Desse modo, a nova redação atribuída pela aludida Emenda à Lei Fundamental, em seu artigo $226, \S 6^{\circ}$, levaria à conclusão de que a ordem constitucional brasileira é orientada, quanto à dissolução da entidade familiar, pelo princípio da ruptura e não mais pelo princípio da culpa, resguardando-se a vida privada do casal (FARIAS; ROSENVALD, 2012b, p. 465), em uma clara alusão ao movimento de afirmação da intervenção mínima do Estado nas relações familiares.

Com isso, o ente estatal não deve interferir no âmbito familiar, preservando o espaço de autodeterminação afetiva de cada pessoa humana integrante do seu núcleo, aceitando a busca da realização plena e da felicidade, por intermédio das opções e comportamentos. A presença estatal nas relações de família justifica-se, apenas, para garantir a proteção especial dedicada aos seus componentes (FARIAS; ROSENVALD, 2012a, p. 158).

Ora, a usucapião especial urbana por abandono do lar encontra plena sintonia com esse movimento de intervenção mínima. Isso porque com a sua criação o ente estatal não está se imiscuindo indevidamente na esfera familiar, pois o tão-só abandono prolongado do lar já justifica e legitima a sua atuação no sentido de tutelar os direitos dos componentes da família desamparada.

Destarte, em nenhuma ocasião é cogitada a necessidade do elemento culpa. Pelo contrário, busca-se efetivar a especial proteção à família e ao indivíduo desamparado, em atenção a princípios e valores constitucionais. 
É cediça a constatação de que o Direito de Família contemporâneo vem se edificando como a expressão mais clara de uma relação jurídica privada, submetida, por consequência, ao exercício da autonomia privada dos indivíduos (FARIAS; ROSENVALD, 2012a, p. 157). No entanto, não se pode conceder a essa autonomia feições absolutas, no sentido de desconsiderar os demais princípios e valores constitucionais que incidem sobre todas as relações familiares.

Até porque, sob a égide do Direito de Família mínimo, a ingerência estatal apenas é admitida nos casos em que tenha como fundamento a proteção dos sujeitos de direito, em especial daqueles vulneráveis, como a criança, o adolescente (FARIAS; ROSENVALD, 2012a, p. 157) e, inclusive, o cônjuge ou companheiro desamparado pelo abandono do lar.

Não se pode conferir à autonomia privada dos integrantes do agrupamento familiar, consubstanciada na figura do abandono do lar, natureza absoluta, sob a falsa premissa de que a sua análise circunscreverá as disposições relativas à culpa. Não é possível olvidar que o abandono tem como consequência a vulnerabilidade de pessoas dotadas de dignidade humana, cuja proteção por parte do Estado é um dever constitucional.

Ressalte-se que em nenhum momento a discussão é orientada pela culpa no abandono do lar. Pelo contrário, ela se assenta nas consequências oriundas desse abandono, isto é, na proteção de sujeitos de direitos fundamentais.

Não há que se falar, em qualquer hipótese, na concretização da culpa para a aquisição da propriedade, mas, sim, na concretização de princípios e valores constitucionais.

Além disso, a argumentação de que a referida usucapião resgata os liames da culpa no Direito de Família não deve prevalecer frente ao direito constitucional à moradia.

A análise do abandono do lar deve ser feita em cada caso, além de totalmente desvinculada do questionamento da culpa pelo fim da relação. Pelo contrário, o questionamento deve perpassar pela análise das condições existenciais mínimas da família ou do indivíduo desamparado, independentemente do elemento culpa no abandono do lar.

Se o indivíduo se ausenta do bem de raiz, por mais de dois anos, voluntariamente, sem que sua presença seja sentida pelos demais membros da família, não é possível condenar a usucapião sob o fundamento de se estar conferindo efeitos jurídicos à culpa.

Esse argumento viola frontalmente a Lei Maior, em especial no que se refere ao direito a uma existência digna, pois caracterizaria obstrução à concretização desse preceito constitucional em face de uma suposta arguição infundada da culpa, em nenhum momento suscitada pelo legislador infraconstitucional. 
Frise-se que a referida forma de aquisição da propriedade prescinde de qualquer discussão a respeito da culpa, de modo que sua relevância está assentada no abandono voluntário, material e afetivo, capaz de impedir que os indivíduos da família desamparada possam ver concretizados as regras e princípios constitucionais anteriormente elencados.

Tanto é assim que nos casos em que a entidade familiar é desfeita mas o cônjuge que deixa o lar continua a prestar auxílios de ordem afetiva e material aos demais integrantes da família não há que se falar em aquisição prescritiva.

Suscitar a culpa como elemento capaz de fundamentar a inconstitucionalidade da usucapião especial urbana por abandono do lar significa, nada mais, defender o retrocesso patrimonialista que figurou no Direito de Família clássico, já que implica deixar de lado todos os princípios, regras e valores constitucionais pertinentes à família e ao indivíduo em detrimento de questões patrimoniais, em uma clara abdicação dos contornos do Direito Civil contemporâneo.

\subsection{Caracterização}

Na seara dos direitos reais, abandono é o ato material em que o proprietário desfaz-se da coisa, em virtude de não desejar mais ser seu dono. Pelo fato de não constituir ato expresso, deve decorrer de atos exteriores que comprovem a manifesta intenção de abandonar, sendo insuficiente o mero desprezo físico pela coisa, caso não acompanhado de marcas evidentes do ânimo de desistir da propriedade (FARIAS; ROSENVALD, 2012b, p. 501).

Em resumo, o mero desuso não implica abandono. É imprescindível a sua conjugação ao elemento psíquico, por intermédio da análise do real interesse do titular de se desfazer da propriedade. Sendo assim, no que diz respeito a bens imóveis, a sua análise se torna muito difícil, já que sua configuração não se dá pelo simples fato de alguém fechar a sua casa. Portanto, o abandono não é presumido, devendo decorrer de atos que virtualmente o contenham (FARIAS; ROSENVALD, 2012b, p. 501).

Desde logo, porém, vale mencionar que o abandono do lar no âmbito da usucapião em destaque não se confunde com o referido abandono do imóvel que dá causa à perda da propriedade. Muito embora exista certa semelhança entre as duas figuras, a configuração do abandono do lar depende da ocorrência de outros fatores, atrelados ao regime jurídico do Direito de Família contemporâneo. 
Destarte, o abandono do lar é o abandono material e voluntário da família, que não é consubstanciado, apenas, pelo afastamento do imóvel. Tanto é assim que caso o cônjuge ou companheiro continue prestando assistência à antiga família, ainda que tenha se ausentado do lar, não está caracterizada a referida usucapião, pois o direito principal por ela assegurado é o direito à moradia, cujo exercício, nesse contexto, está sendo alvo de assistência por parte do indivíduo que abandonou o lar.

Desse modo, à luz da constitucionalização ${ }^{7}$ e da repersonalização ${ }^{8}$ do Direito de Família, é possível concluir que o abandono do lar, para efeitos legais, deve ser (i) voluntário, (ii) material e (iii) afetivo.

Apenas a partir da conjugação desses três requisitos, portanto, pode-se sustentar a aplicação da usucapião especial urbana por abandono do lar no sistema normativo brasileiro.

\subsubsection{Voluntário}

No que diz respeito à voluntariedade, ela pode estar presente tanto na saída do lar, ou seja, caso o cônjuge ou companheiro deixe o lar voluntariamente, quanto na não prestação de assistência material ou afetiva, desde que, obviamente, estejam caracterizados os demais requisitos exigidos em lei. Com isso, não se pode restringir a usucapião aos casos em que apenas o abandono do lar ocorra de maneira voluntária.

É plausível imaginar, como exemplo, a situação em que o marido é obrigado a se afastar do lar em virtude de medida protetiva concedida judicialmente em favor de sua esposa, com fundamento na Lei $\mathrm{n}^{\mathrm{o}} 11.340 / 06$, a Lei Maria da Penha. Nesses casos, ainda que o abandono do lar não seja voluntário, o fato de o marido deixar de prestar assistência material à entidade familiar, por si só, já é capaz de configurar o elemento voluntariedade, ensejando a perda da propriedade imóvel.

Por sua vez, é necessário que essa voluntariedade do abandono seja analisada a partir da ótica dos valores constitucionais em jogo, sobretudo em virtude da natureza social da Lei $\mathrm{n}^{\mathrm{o}} 12.424 / 11$. Desse modo, para que se configure o abandono voluntário é preciso investigar

\footnotetext{
${ }^{7}$ Cristiano Chaves de Farias e Nelson Rosenvald (2012a, p. 80), vale frisar, explicam que a constitucionalização do Direito de Família “[...] significa, mais propriamente, impor a compreensão das normas e dos institutos de Direito das Famílias - e do Direito Privado como um todo, a partir de uma filtragem constitucional, reconhecendo a superioridade da norma básica do Estado".

${ }^{8}$ A família como ambiente propício à realização da afetividade humana enquadra-se no "[...] fenômeno jurídicosocial denominado repersonalização das relações civis, que valoriza o interesse da pessoa humana mais do que suas relações patrimoniais. É a recusa da coisificação ou reificação da pessoa, para ressaltar sua dignidade. A família é o espaço por excelência da repersonalização do direito" (LÔBO, 2011, p. 22, grifo nosso).
} 
todos os princípios e valores constitucionais, identificando, em cada caso concreto, quais os elementos integrantes da conduta do cônjuge ou companheiro que se ausenta do lar.

Assim, não há que se falar em usucapião especial urbana por abandono do lar nas hipóteses em que a mulher, p. ex., é espancada pelo cônjuge ou companheiro e sai da casa para que as agressões sejam interrompidas. Isso porque a voluntariedade, nessas situações, encontra-se tutelada por valores constitucionais, como a dignidade da pessoa humana e o direito à integridade psicofísica, de maneira a não permitir a perda da propriedade imóvel, sob pena de essa consequência ser incompatível com o sistema normativo brasileiro.

\subsubsection{Material}

Da construção de uma vida em comum emanam diversos efeitos jurídicos, que se mostram presentes tanto no campo pessoal quanto no âmbito econômico. Como se trata de uma comunhão de vida, com o objetivo de servir ao desenvolvimento fisiopsíquico da pessoa humana, todas as comunidades familiares projetam implicações na seara de seus integrantes e na de seu patrimônio (FARIAS; ROSENVALD, 2012a, p. 313).

Nesse sentido, Cristiano Chaves de Farias e Nelson Rosenvald (2012a, p. 313) afirmam que: “[...] considerado o caráter indiviso da comunhão de vida, chega-se à fatal conclusão de que a união entre dois seres humanos, marcada pela afetividade, traz consigo uma conjugação de aspectos emocionais/espirituais e aspectos materiais [...].”.

Uma relação familiar não é composta tão-somente pelo afeto. Qualquer família é dotada de questões patrimoniais relevantes, como a assistência recíproca, a guarda, sustento e educação dos filhos e a manutenção do lar. É importante lembrar que “[...] toda e qualquer entidade familiar é marcada pela imperativa necessidade de realizar determinadas utilidades, em favor dos parceiros, de sua prole [...] para que todos vivam com dignidade, realizando-se plenamente" (FARIAS; ROSENVALD, 2012a, p. 313-314).

Isso significa que, nas entidades familiares, a comunhão de vidas implica uma verdadeira comunhão de interesses econômicos, de maneira que os seus integrantes assumem a solidária responsabilidade de cuidar do sustento do lar, sendo responsáveis pelas despesas comuns para a manutenção da família (FARIAS; ROSENVALD, 2012a, p. 314).

Destarte, em relação aos efeitos oriundos da usucapião especial urbana por abandono do lar, não se pode duvidar da importância do abandono material para a sua caracterização. Em havendo um dever de auxílio material intrínseco à própria existência da vida familiar, 
nada mais óbvio do que o abandono material constituir elemento necessário para a perda da propriedade imóvel.

Desse modo, não há espaço para a usucapião se o cônjuge ou companheiro, não obstante abandone voluntariamente o lar, continue a prestar assistência econômica e material ao indivíduo desamparado e à família. Isso porque, com tal atitude, há o afastamento da precarização dos valores tutelados pela aquisição prescritiva, de maneira que a perda da propriedade passa a não ser mais o meio adequado para a proteção da entidade familiar, vez que a sua tutela já vem sendo realizada pelas ações do cônjuge ou companheiro que se ausentou do imóvel.

\subsubsection{Afetivo}

É cediça a constatação de que a família vem se transformando na medida em que se acentuam as relações de sentimentos entre os seus integrantes, de modo que as funções afetivas da entidade familiar passaram a ser amplamente valorizadas. O Direito de Família encontra-se sob a égide de um novo paradigma, cuja atribuição de valor jurídico ao afeto se mostra presente (DIAS, 2010, p. 70-71).

A grande preocupação com os interesses patrimoniais que marcou o Direito de Família tradicional não encontra fundamento na família atual, cuja base se assenta em outros interesses de cunho pessoal, reunidos por um elemento aglutinador e nuclear distinto, que confere o suporte fático do agrupamento familiar tutelado pela Constituição: a afetividade (LÔBO, 2011, p. 25-26).

A partir da compreensão da família como instrumento de promoção do desenvolvimento da personalidade de seus membros, essa entidade traz consigo uma nova feição, assentada, agora, na solidariedade e no afeto, o qual "[...] caracteriza a entidade familiar como uma verdadeira rede de solidariedade, constituída para o desenvolvimento da pessoa [...]" (FARIAS; ROSENVALD, 2012a, p. 153).

Após o individualismo que dominara os dois últimos séculos, a família contemporânea procura sua identificação na solidariedade - objetivo da República constitucionalmente estabelecido - como uma das bases da afetividade, ainda que não resgate o papel preponderante que exerceu no mundo antigo (LÔBO, 2011, p. 18).

A realização pessoal da afetividade, em meio a um cenário de convivência e solidariedade, é a função precípua da família atual, cuja reinvenção social trouxe como 
consequência a constatação da sua unidade no afeto. "[...] A afetividade, assim, desponta como elemento nuclear e definidor da união familiar, aproximando a instituição jurídica da instituição social [...]” (LÔBO, 2011, p. 20).

A afetividade é um princípio ${ }^{9}$ (DIAS, 2010, p. 70) tutelado pelo ordenamento jurídico brasileiro. Isso implica dizer que, à luz da usucapião especial urbana por abandono do lar, não se pode admitir a perda da propriedade de um cônjuge ou companheiro que, não obstante tenha abandonado o lar de maneira voluntária e não contribua materialmente com o sustento do indivíduo desamparado e da família por razões justificáveis, continue prestando-lhes assistência afetiva.

A repercussão econômica não prevalece em face do caráter afetivo-solidarista das famílias. As consequências patrimoniais das relações familiares devem estar relacionadas com a proteção da dignidade humana e de seus valores existenciais. Tanto é assim que as relações patrimoniais estabelecidas no seio familiar devem, necessariamente, ser informadas por princípios que garantam a primazia da proteção humana (FARIAS; ROSENVALD, 2012a, p. $315)$.

Desse modo, para que a usucapião advenha do abandono do lar é imprescindível a cumulação dos requisitos anteriormente mencionados. A partir da análise constitucional da família e da propriedade, percebe-se que apenas o abandono voluntário, material e afetivo pode fundamentar a perda da propriedade imóvel, pois somente ele é capaz de violar os preceitos constitucionais que conferem primazia à realização da dignidade humana dos membros da entidade familiar.

\section{O VOCÁBULO “EX” NO DISPOSITIVO LEGAL: SITUAÇÃO DE FATO}

Nesse momento, cumpre destacar a existência de um importante erro na elaboração do texto legal da usucapião especial urbana por abandono do lar, relacionado à situação dos cônjuges ou companheiros quando do oferecimento da ação de usucapião.

\footnotetext{
${ }^{9}$ Nesse mesmo sentido, Paulo Lôbo (2011, p. 71) também reconhece a força normativa da afetividade: “O princípio da afetividade está implícito na Constituição. Encontram-se na Constituição fundamentos essenciais do princípio da afetividade, constitutivos dessa aguda evolução social da família brasileiro [...]: a) todos os filhos são iguais, independentemente de sua origem (art. 227, § $6^{\circ}$ ); b) a adoção, como escolha afetiva, alçou-se integralmente ao plano da igualdade de direitos ( $\operatorname{art} .227, \S \S 5^{\circ}$ e $6^{\circ}$ ); c) a comunidade formada por qualquer dos pais e seus descendentes, incluindo-se os adotivos, tem a mesma dignidade de família constitucionalmente protegida (art. 226, $\S 4^{\circ}$ ); d) a convivência familiar (e não a origem biológica) é prioridade absoluta assegurada à criança e ao adolescente (art. 227)”.
} 
Isso porque o legislador utilizou-se, equivocadamente, do vocábulo "ex" para ser referir ao cônjuge ou companheiro que abandonou o lar, o que, em uma primeira visão, implicaria a necessidade de reconhecimento jurídico da dissolução da entidade familiar.

No entanto, parece claro que, a partir de uma interpretação sistemática do ordenamento jurídico, basta o abandono, isto é, a situação de fato, para que esteja configurada a hipótese da usucapião. Não há que se falar, por exemplo, em ação de divórcio como requisito necessário previsto na lei.

Ora, o reconhecimento jurídico da dissolução do casamento ou da união estável costuma trazer consigo discussões patrimoniais, as quais, como já mencionado, impedem a concretização da usucapião por abandono do lar.

O texto da lei determina a ausência de discussão judicial acerca da propriedade imóvel, de modo que exigir o reconhecimento jurídico da dissolução da entidade familiar significaria reconhecer a própria inaplicabilidade da aludida forma de aquisição prescritiva no direito brasileiro.

\section{DESTINAÇÃO DO IMÓVEL PARA MORADIA}

Em sintonia com um dos principais direitos fundamentais positivados pela Constituição Federal, diretamente relacionado à usucapião especial urbana por abandono do lar, o legislador ordinário estabeleceu a necessidade de que o imóvel a ser usucapido tenha como destinação a moradia do indivíduo desamparado ou de sua família.

Com isso, a aquisição da propriedade só será possível nas hipóteses em que o bem de raiz é utilizado para moradia da entidade familiar, em uma clara referência à subordinação dos efeitos da usucapião a uma especial proteção da pessoa humana e da família.

Não é possível, portanto, a sua ocorrência nas situações em que, ao imóvel comum do casal, seja dada destinação econômica, encontrando-se articulado em função da exploração de uma atividade empresarial. A lei não tem como finalidade a proteção da empresa ou de elemento conexo, mas, sim, do agrupamento familiar e da pessoa humana a ela vinculada.

\subsection{Aplicação do instituto aos imóveis rurais destinados à moradia: necessidade}


O principal problema que pode ser encontrado no artigo 1.240-A do Código Civil está relacionado à infundada restrição da usucapião por abandono do lar apenas aos imóveis urbanos. Dessa forma, a entidade familiar rural está posicionada à margem da especial proteção que lhe é devida por disposição constitucional, sem que haja qualquer justificativa para tanto.

Cumpre destacar que nas situações em que a moradia da família está localizada na zona rural, a divisão patrimonial seguirá o regime ordinário do Direito de Família (FARIAS; ROSENVALD, 2012b, p. 467). Destarte, não há qualquer argumento ou norma jurídica capaz de fundamentar essa inadequada exclusão da organização familiar rural da devida proteção legal.

Pelo contrário, tendo em vista as dificuldades oriundas da vida rural, o direito faz nascer uma série de elementos que conferem a essas pessoas tratamento jurídico diferenciado, em face de sua posição de desigualdade, em diversos aspectos, em comparação com o homem urbano. Como exemplo pode-se mencionar o regime de seguridade social diferenciado para o trabalhador rural, por disposição constitucional expressa (artigo 195, $\S 8^{\circ}$ ).

A propriedade rural que se centra na terra como bem de produção carrega consigo uma destinação voltada à produção de riquezas e à criação de empregos, em contraposição ao imóvel urbano, que se destina, naturalmente, à moradia (FARIAS; ROSENVALD, 2012b, p. 332). Entretanto, nem toda propriedade rural tem a sua exploração voltada para a produção de renda, de modo que sua destinação pode se orientar, também, para a moradia de seus proprietários.

Assim, não se pode admitir que a entidade familiar que exerça sua moradia em imóvel rural não seja protegida pela aludida usucapião, mesmo porque os fins sociais da lei não apontam para uma proteção restrita aos imóveis urbanos, mas, sim, para a tutela do direito fundamental à moradia, pouco importando o local de seu exercício.

Deve-se evocar o princípio da igualdade, positivado constitucionalmente (artigo $5^{\circ}$ ), no sentido de se coibir tratamento diferenciado que prejudique a família cuja propriedade rural seja destinada à moradia.

Paulo Lôbo, após constatar as profundas mudanças inseridas pelo aludido princípio no Direito de Família, lembra que:

O princípio constitucional da igualdade (a fortiori normativo) dirige-se ao legislador, vedando-lhe que edite normas que o contrariem, à administração pública, para que programe políticas públicas para superação das desigualdades reais existentes entre os gêneros, à administração da justiça, para o impedimento das 
desigualdades, cujos conflitos provocaram sua intervenção, e, enfim, às pessoas que o observem em seu cotidiano (LÔBO, 2011, p. 66, grifo nosso).

Como não é possível vislumbrar qualquer justificativa plausível que sustente a restrição ao instituto imposta pelo legislador, tem-se uma verdadeira violação ao princípio constitucional da igualdade, algo que não pode ser deixado de lado quando da aplicação da usucapião especial urbana por abandono do lar pelo magistrado.

Por intermédio de uma interpretação teleológica da lei é plenamente viável estender a sua proteção às famílias rurais, vez que, como já mencionado, sua finalidade precípua se assenta na concretização do direito constitucional à moradia e da dignidade da pessoa humana.

Uma interpretação sistemática da lei implica a consideração de todas as regras, princípios e valores abrangidos pelo ordenamento jurídico. Desse modo, é possível identificar preceitos normativos e constitucionais como (i) a garantia da dignidade da pessoa humana, (ii) a solidariedade social e familiar, (iii) o direito à integridade psicofísica; (iv) o direito ao míninimo existencial, (v) especial proteção à família e (vi) função social e individual da propriedade, por meio dos quais a aplicação da aludida usucapião aos imóveis rurais destinados à moradia não se torna apenas uma medida viável, mas obrigatória.

\section{CONCLUSÃO}

Por se tratar de um instituto muito recente, a usucapião especial urbana por abandono do lar vem suscitando uma série de questionamentos entre os juristas e aplicadores do direito.

Com base em uma interpretação do Código Civil à luz da Lex Fundamentalis, é possível verificar cinco requisitos cumulativos e necessários para a sua configuração.

Nesse sentido, faz-se mister que o indivíduo desamparado pelo abandono exerça, por dois anos ininterruptos, posse direta, importantíssima para a aquisição da propriedade, vez que uma de suas finalidades principais é a garantia do direito à moradia da família abandonada.

Além disso, essa posse deve ser exclusiva e sem oposição, o que implica dizer que, caso haja uma recomposição do núcleo familiar afetado pelo abandono do bem de raiz, não há que se falar em usucapião, vez que o vazio deixado pelo cônjuge ou companheiro já fora devidamente preenchido.

O imóvel, de até duzentos e cinquenta metros quadrados, deve ser comum do casal, ou seja, abrangido pelo regime de bens do casamento ou pelos efeitos da união estável. Em 
outras palavras, não se admite que a usucapião recaia sobre bem titularizado por terceiro, ainda que o casal exerça a composse direta.

Um imóvel, inclusive, que, a despeito da expressa previsão legal e com base nos ditames da hermenêutica constitucional, pode ser urbano ou rural, desde que destinado à moradia dos indivíduos desamparados ou de sua família. Essa é a medida que se impõe em virtude de a usucapião tutelar o direito à moradia, qualquer que seja o local de seu exercício.

Por sua vez, o seu requisito mais polêmico é o abandono do lar, que não dá ensejo a qualquer discussão a respeito da culpa do cônjuge ou companheiro que se ausenta do imóvel.

Trata-se de um abandono que reúne três qualidades: (i) voluntário, salvo se essa voluntariedade estiver tutelada pela Constituição; (ii) material, não sendo possível defender a perda do direito de propriedade do indivíduo que se ausenta do lar, mas continua contribuindo para o sustento família, afastando a sua precarização; e (iii) afetivo, de modo a evitar a prevalência de qualquer repercussão patrimonial em detrimento do caráter sócio-afetivo da organização familiar contemporânea.

Por fim, no momento atual, não é possível definir, de maneira exata, todos os seus efeitos na ordem jurídica, sendo imprescindível uma futura identificação de como a jurisprudência e até mesmo a doutrina irão recepcionar essa forma de aquisição prescritiva.

Certo é que ela diz respeito a um instituto em vigor no Brasil, que tem o condão de afastar uma utilização injusta da propriedade imobiliária, visando à proteção da dignidade humana daquele indivíduo afetado pelo abandono do lar de um dos mais importantes membros da família, concretizando a sua especial proteção imposta pelo texto constitucional.

\section{REFERÊNCIAS}

AMARAL, Francisco. Direito civil: introdução. 7. ed. Rio de Janeiro: Renovar. 2008.

BRASIL. Conselho da Justiça Federal. Enunciado no 498. Disponível em: < http://www.jf.jus.br/cjf/cej-publ/Compilacao\%20enunciados\%20aprovados1.pdf $>$. Acesso em: 01.03.13.

DIAS, Maria Berenice. Manual de Direito das Famílias. 7. ed. São Paulo: Editora Revista dos Tribunais, 2010. 
FARIAS, Cristiano Chaves de; ROSENVALD, Nelson. Curso de Direito Civil: direito das famílias. 4. ed. Salvador: Editora JusPODIVM, 2012a.

Curso de Direito Civil: direitos reais. 8. ed. Salvador: Editora JusPODIVM, 2012b.

GONÇALVES, Carlos Roberto. Direito Civil brasileiro: direito das coisas. 5. ed. São Paulo: Saraiva, 2010.

Direito civil brasileiro: parte geral. 9. ed. São Paulo: Saraiva, 2011.

LIMA, Suzana Borges Viegas de. Por um estatuto jurídico das relações homoafetivas: uma perspectiva civil-constitucional. In: LIMA, Frederico Henrique Viegas de; GRANJEIRO, Ivonete [orgs.]. Direito civil constitucional. Brasília: Editora Obcursos, 2009.

LÔBO, Paulo. Direito Civil: famílias. 4. ed. São Paulo: Saraiva, 2011.

Teoria Geral das Obrigações. São Paulo: Saraiva, 2005.

MORAES, Maria Celina Bodin de. A constitucionalização do direito civil e seus efeitos sobre a responsabilidade civil. Direito, Estado e Sociedade. v. 9. p. 233-258. jul./dez. 2006.

TEPEDINO, Gustavo. O Código Civil, os chamados microssistemas e a Constituição: premissas para uma reforma legislativa. In: [coord.]. Problemas de Direito Civil-Constitucional. Rio de Janeiro: Revonar. 2001. p. 01-14.

WALD, Arnold. Direito civil: introdução e parte geral. 13. ed. São Paulo: Saraiva, 2011. 